doi: 10.52370/TISC21198DI

\title{
IMPACT OF PANDEMIC ON SELECTIVE DEVELOPMENT OF TOURISM IN SOUTHERN AND EASTERN SERBIA
}

\author{
Dragana Ilić ${ }^{1}$; Predrag Stamenkovic $c^{2}$
}

\begin{abstract}
Natural and anthropogenic tourist values, along with the appropriate tourist infrastructure and superstructure, represent the basis for the development of tourism in an area. In modern conditions, when it comes to tourist demand, there are more and more specific motives that encourage tourists to travel. This leads to the segmentation of tourist demand and opportunities for the development of selective forms of tourism. The aim of this paper is to consider the possibilities for the development of selective types of tourism in the region of Southern and Eastern Serbia and the specifics of regional tourism development in the conditions of Covid-19 pandemic.
\end{abstract}

Key Words: selective tourism, pandemic, Southern and Eastern Serbia JEL classification: Z32, R11, R41

\section{Introduction}

Changes on the side of tourist demand, in terms of needs, requirements, habits, motives and interests, have conditioned the emergence of selective forms of tourism. Specific motives that encourage tourists to travel are culture, gastronomy, religion, sports, hunting, fishing, fashion, film, music, photography, sailing, entertainment, events. Tourist destinations, on the side of the tourist offer, in order to meet the specific requirements and needs of tourists, base their development on a concept that relies on the specific motives of a particular target segment of tourist demand. Tourists are changing their habits, becoming more demanding and sophisticated.

\footnotetext{
${ }^{1}$ Dragana Ilić, Ph.D., senior lecturer, Academy of Vocational Studies Southern Serbia, Partizanska 7, Leskovac, Serbia, 016254961, ilic.dragana@vpsle.edu.rs

${ }^{2}$ Predrag Stamenković, Ph.D., professor, Academy of Vocational Studies Southern Serbia, Partizanska 7, Leskovac, Serbia, 016254961, stamenkovic.predrag@ vpsle.edu.rs
} 
Tourists, primarily solvent tourists, as well as tourists with strong knowledge and experience when it comes to travel, are constantly looking for new tourism products and experiences. All this leads to the creation and adaptation of a tourist product in line with the needs and requirements of modern tourists. The concept of selective tourism, unlike the concept of mass tourism, focuses on the tourist as an individual, ie creating a tourist product and a tourist offer that will satisfy the requirements of the tourist as an individual. The region of Southern and Eastern Serbia has significant natural and anthropogenic tourist values. Attractive geomorphological values, favorable climatic conditions, significant hydrological potential, diverse flora and fauna, rich cultural and historical heritage, ethnographic and manifestation tourist values provide opportunities for the development of selective types of tourism in this area. In the region, therefore, there is an opportunity for the development of different types of tourism, each of which requires a special approach to development.

The Covid-19 pandemic and related restrictive measures are causing enormous damage to economies around the world, with tourism being one of the hardest hit. In the following, the basis for the development of selective types of tourism in the region of Southern and Eastern Serbia and the specifics of the development of tourism in this region in the conditions of a pandemic will be considered. In addition, an analysis of tourist traffic in the region in the period 2010-2020 will be performed, with special reference to the turnover that was realized in the year of the Covid-19 pandemic.

\section{The basis for the differentiation of selective forms of tourism in the region of Southern and Eastern Serbia}

A certain area attracts tourists on the basis of the area attractiveness, such as natural and anthropogenic resources that the area has at its disposal (Stanković, 2003). Proper use of tourist resources and proper management of tourism development in the region requires a good knowledge of the internal and external environment, all the advantages, disadvantages, opportunities and threats in the development of tourism.

Selective types of tourism encourage regional tourism development and highlight the region's comparative advantages. "Selective tourism occurs in response to the negative implications of mass tourism. Through the diversification of the tourist offer, the tourist product is adapted to smaller groups of tourists" (Ćorluka et al., 2013, p. 91). The development of 
specific types of tourism is based on the offer of unique values. "An optimal combination of the strategic management models in this tourism destination should be reserved to the selection and implementation of the strategy of tourism segmentation, in order to gain and to categorize target market segments and a particular group of tourists with a precisely known needs and desires" (Stamenković \& Ilić, 2017, p. 657). In order to talk about the successful development of specific types of tourism in a tourist destination, their promotion and placement, it is necessary to recognize all the positive and negative factors for the development of a tourist destination.

In order to identify all the advantages and all the disadvantages for the development of tourism in the region, it is necessary to perform an appropriate analysis of internal potentials. This implies inventory and classification of all elements of attractive tourist potential in the region. To achieve this goal, it is especially important to identify affirmative and limiting factors in the development of selective types of tourism in this area and critically approach their analysis in order to enable selective tourism development and raise the level of destination competitiveness in Southern and Eastern Serbia.

Mountains, picturesque nature and favorable climate are a good basis for the development of mountain tourism, excursion tourism and outdoor activities. The richness and diversity of thermo-mineral springs enable the development of spa tourism in this area. A special curiosity are the geysers as special tourist values in Sijarinska and Lukovska spas. Numerous lakes with beautiful surroundings provide opportunities for water activities, camping. Villages in the region of Southern and Eastern Serbia represent the potential for the development of eco-tourism. "One of the most important segments in the gastronomy sector, could be locally produced agricultural products. Such products, in many countries, their regions and cities, occupy an enviable percentage of the share in the tourism consumption" (Stamenković \& Đeri, 2016, p. 1261). The autochthonous gastronomic offer of many places in the region represents a good basis for the development of gastronomic tourism. A large number of cultural monuments, archeological sites, famous places, spatial cultural - historical units and religious buildings represent a significant potential for the development of cultural and religious tourism in the region of Southern and Eastern Serbia. Hotels in larger cities and some spa centers have the conditions for organizing conferences, seminars, congresses and other business meetings, which is the basis for the development of congress 
tourism. Numerous manifestations of different character (ethnographic, artistic, entertainment, sports, religious, economic manifestations) represent the potential for the development of manifestation tourism in the region. Sports fields, swimming pools, sports halls and other sports and recreational facilities, as well as numerous places in nature, represent the potential for the development of sports and recreational tourism. Hiking and mountain biking routes, among other things, are the basis for the development of adventure tourism. Numerous hunting areas in the region inhabited by different species of game represent the potential for the development of hunting tourism. Rivers represent a kind of potential for the development of fishing tourism, as well as for bathing and water activities.

The mountains represent a particularly significant geomorphological tourist value, due to their vastness, properties and landscape diversity. Mountains in the region of Southern and Eastern Serbia (Stara planina, Suva planina, Rtanj, Ozren, Homoljske planine, Radan planina, Besna Kobila and others) represent a unique natural wealth and provide opportunities for activities such as skiing, hiking, recreation, collecting medicinal plants, extreme sports, paragliding and jeep driving. The mountains provide opportunities for the development of mountain tourism, as well as rural, congress, cycling, hunting, excursion and sports - event tourism. Most of the mountains in this region, however, have not yet been discovered and are characterized by untouched nature. Gorges (Đerdapska, Sićevačka and others) and canyons (Lazareva river canyon, canyon of Rosomača, canyon of river Jerma, canyon of Vučjanka) deserve special attention, as a special type of geomorphological tourist values. Caves represent a special type of geomorphological tourist values and a segment of the tourist offer. From the caves that are arranged for tourist visits, we should single out Ceremošnja and Ravništarka (near Kučevo), the complex of Zlotski caves (near Bor), Rajkova cave (near Majdanpek) and Bogovinska cave (near Boljevac). In the region of Southern and Eastern Serbia, there are two geomorphological phenomena that are unique in Europe. These are Đavolja varoš (near Kuršumlija) and Vražji kamen (near Trgovište). Only the Đavolja varoš has been valorized for tourism - a natural phenomenon that is visited by a large number of tourists every day.

The region of Southern and Eastern Serbia has a rich hydrological potential. It can be said that this is a region of spas and the most diverse thermomineral waters. The number and diversity of thermo-mineral springs have conditioned the emergence of a large number of spas in this region. Spas 
have the opportunity to form a diverse tourist offer. Only a small number of spas in the region have taken advantage of these opportunities. These are the spas that create a tourist offer in accordance with the requirements of modern tourists and create programs that will attract tourists and visitors throughout the year. In addition, there are rivers and lakes that attract the attention of a large number of tourists thanks to their tourist potential. The Danube River stands out for its importance. Given that the Danube flows through Eastern Serbia, providing exceptional opportunities for panoramic sightseeing and visits to numerous places rich in cultural and historical heritage, there is potential for the development of nautical tourism in this part of the country. For the development of nautical tourism, it is necessary to create specific technical - technological and organizational - personnel conditions. In addition, the development of this type of tourism implies the use of nautical infrastructure and superstructure, which is insufficiently developed in this part of the country, as well as in the whole country. The lakes in the region of Southern and Eastern Serbia, with their geographical position, quality and physical properties of water, as well as the living world in them, attract the attention of domestic and foreign tourists and provide opportunities for various tourist activities. Some lakes represent independent tourist values, while others have a complementary character when it comes to the tourist offer of a specific area. Some lakes in this region are not sufficiently valorized. Springs are a special type of hydrographic tourist values. Due to their unique beauties, they are part of the tourist offer of the area where they are located. In the region of Southern and Eastern Serbia, the Krupajsko spring at the foot of the Beljanica mountain, the Mlava spring near Žagubica and the Krupačko spring (Blue Eye) in the village of Krupac near Bela Palanka stand out for their specifics. These places are tourist attractions characterized by clear water and lush vegetation. Waterfalls are special tourist attractions and places that are visited, above all, by nature lovers. More than a third of all waterfalls in Serbia are located on Stara Planina (in the region of Southern and Eastern Serbia). In addition to the waterfalls on Stara Planina, the region also features a waterfall near Negotino, a waterfall at the foot of Kucaj mountain, a waterfall in the Djerdap National Park, a waterfall on the slopes of Beljanica, as well as a waterfall near Kučevo. Many of these waterfalls, especially on Stara Planina, are located in inaccessible areas and are difficult to reach.

On the territory of Southern and Eastern Serbia, there are numerous species of flora and fauna, ie a diverse flora and fauna. The region has a variety of medicinal, aromatic and rare plants and fruits. This area is also 
characterized by an abundance of game species in the forests, fish in the waters, birds and butterflies. It provides opportunities for hunting, fishing, photography and the like. The richness and diversity of flora and fauna in a way increases the value of the tourist offer of this area. The richness of flora and fauna can greatly improve the content of your stay in a tourist destination. Therefore, special attention must be paid to the preservation and protection of plant and animal species. In the region of Southern and Eastern Serbia, there are a large number of internationally important areas for plants, several internationally important areas for birds and areas for butterflies. There are a large number of protected natural areas in the region. These properties are special tourist attractions that provide opportunities to stay and enjoy nature.

The rich cultural and historical heritage of Southern and Eastern Serbia (numerous churches, monasteries, fortresses, museums, famous places, archeological sites, one of which is on the UNESCO World Heritage List) represents an exceptional potential for the development of cultural tourism in this area. It depicts the history, culture and tradition of the people in those areas. The region is characterized by a rich gastronomic offer based on the specifics of the environment and the influence left by different peoples who passed through this area.

Adventure tourism is a type of tourism that is just beginning to develop in Serbia. This type of tourism takes place in a natural environment, it involves moving to unexplored areas, extreme sports and a greater or lesser level of risk. The region of Southern and Eastern Serbia is the second region in Serbia in which the development of adventure tourism could be intensified. This region, namely, has the potential for paragliding, recreational hiking, free climbing, mountain biking and other adventurous activities.

Limiting factors in the process of creating a tourist offer and the development of tourism in the region of Southern and Eastern Serbia refer to the high share of the population aged 60 and over in the total population. This region is characterized by a deep demographic age, which is one of the limiting factors in development. In addition, the share of residents with primary and incomplete primary education is high, and the share of the population with higher education is low. Good development of traffic infrastructure, tourist infrastructure and superstructure is very important for creating a quality and attractive tourist offer. The level of infrastructure development in this region is not satisfactory. This requires special 
attention, planning and implementation of activities in these areas in order for the destinations of the region of Southern and Eastern Serbia to enter the tourist market with a better tourist offer. Accommodation capacities in the region of Southern and Eastern Serbia, in terms of quality, lag far behind accommodation capacities in other regions, primarily for accommodation capacities in the Belgrade region and in the region of Vojvodina. Catering facilities for accommodation and food should undertake activities in terms of improving quality through the introduction of international standards of accommodation, preparation and serving of food and beverages. In addition, the activities of these facilities should be aimed at improving the quality of promotion, reservation and payment of accommodation. Some of the most important limiting factors, therefore, are: unfavorable demographic trends, insufficiently developed general infrastructure, as well as tourist infrastructure and superstructure, inadequate marketing concept in the promotion of tourist offer, insufficient financial support and the like (Ilić \& Stamenković, 2019).

Continuous education of staff in the field of tourism and more intensive promotion of the tourist offer is especially important. In order to create a quality tourist offer and an appropriate appearance on the domestic and international tourist market, it is necessary to use all stimulating factors, and to eliminate or mitigate the effect of limiting factors in the development of tourism. There are many elements and factors that affect the competitiveness of a tourist destination, and which are of crucial importance in setting competitiveness for the primary issue (Stamenković \& Đeri, 2018). In modern conditions, it is especially important to constantly improve the tourist offer, research the specific needs and requirements of modern tourists and create specific tourist products that are in line with these needs and requirements.

\section{Specifics of tourism development in the region of Southern and Eastern Serbia in the conditions of the Covid-19 pandemic}

The Covid-19 pandemic undoubtedly affects all segments of human life. It influenced a completely different view of people on life and daily activities. Due to the pandemic, there was a change in the way of life, work, realization of daily activities, and loss of the opportunity to satisfy secondary needs, which also includes tourist needs. Travel has a special, multiple significance for people, and in the conditions of a pandemic, they are maximally limited, while at one point they were impossible. The announcement of the COVID-19 pandemic indicated a significant impact 
on economic developments and trends (Praščević, 2020). In the conditions of the Covid-19 pandemic, tourism is one of the activities that suffers the greatest losses and negative consequences of the pandemic. The pandemic affects the impossibility and limitations of the realization of tourist trips all over the world. In such circumstances, the importance of tourism and its impact on people's quality of life is understood. Experience of pandemic create "new consciousness" and consequently will change tourism (Telišman-Košuta, 2020).

After a certain period of isolation and limited movement at the beginning of the pandemic, people increasingly wanted to get involved in tourist movements. Restrictions that remained in force made destinations inaccessible to tourists in Europe and the world. It is, on the other hand, an ideal opportunity for tourist movements to take place in a national context, to discover and experience many destinations in the country that are worth the attention of tourists. In that sense, vouchers for subsidized use of accommodation services have a significant contribution, which, by the way, aim to encourage the development of domestic tourism. The National Tourism Organization has made a huge effort to promote tourist destinations in the country and send the message "stay at home today, to travel tomorrow", which is the slogan of the World Tourism Organization (UNWTO, 2021).

During the Covid-19 pandemic, tourists were sent to domestic destinations. Having in mind the epidemiological situation and the number of people in big cities, domestic tourists choose destinations with a smaller number of people and a peaceful environment. There are many such destinations in the region of Southern and Eastern Serbia. With the desire to avoid city crowds and an unstable epidemiological situation, people chose mountains, national parks, rivers, lakes and attractive open spaces that minimize epidemiological risk. According to the author Mojić (2012) "the region of Southern Serbia is a very interesting tourist destination in its geographical position (crossroads), with exceptional natural beauty, cultural and historical values, favorable climatic conditions, rich rivers, lakes and thermal waters" (p. 148). The region of Southern and Eastern Serbia has always been considered insufficiently explored in terms of tourism. There are numerous destinations in the region with attractions that would capture the attention of tourists. Many of these destinations are unknown to domestic tourists, due to insufficient promotion, but also insufficient interest of domestic tourists to get to know the natural and anthropogenic tourist values in this area. 
Due to the high epidemiological risk posed by travel to other countries, tourists in a pandemic have the opportunity to learn more about destinations in the national context and, thus, with the diverse resource base that the region of Southern and Eastern Serbia has. Destinations in this region offer tourists a clean and healthy natural environment, healthy food, a large number of nature parks and landscapes of exceptional features, nature reserves, natural monuments, spas and mountain centers, monasteries, religious sites, archeological sites, museums, fortresses and the national park.

In addition, certain areas provide opportunities for adventure activities, sports and recreational activities in nature, on a large number of rivers and lakes. For certain segments of tourist demand, it is important to differentiate resources in entering the tourist market, while for certain segments of tourist demand, on the other hand, it is necessary to combine available resources and present a unified tourist offer of individual districts or regions as a whole.

After the pandemic, tourism is going to need changes based on planning that emphasizes the health, education and environmental dimensions (Sharma et al., 2020). Tourism is likely to recover gradually, ie destinations will go through several different phases of recovery until finally reaches the pre-crisis level of tourism activity (Krešić \& Mikulić, 2020). To improve the quality of the offer and more intensive development of tourism in the region in the period after the pandemic, the following measures and activities should be taken: development of selective types of tourism, in accordance with the rich and diverse tourist potential; development of transport and communal infrastructure; development of tourist infrastructure and superstructure; construction of new and renovation of existing accommodation capacities; improvement of tourist signalization; development of a positive image for better positioning in the market; harmonization of events in different municipalities of the district; implementation of programs for protection and development of natural and anthropogenic tourist values; strengthening the awareness of the community about the preservation of tourist values and the importance of tourism development in the region; education of staff in the field of tourism; production of quality promotional material and intensification of promotional activities. 


\section{Analysis of tourist traffic in the region of Southern and Eastern Serbia in the period 2010-2020.}

The analysis of tourist traffic in the region of Southern and Eastern Serbia in the period 2010-2020 will be presented below, based on the data from the Republic Statistical Office. The participation of the region in the total number of tourist arrivals and overnight stays in Serbia will be considered, as well as the arrivals and overnight stays of domestic and foreign tourists in the region, in the observed ten-year period.

Table 1: Participation of the Southern and Eastern Serbia region in the total number of tourist arrivals and overnight stays in the Republic of Serbia in the period 2010-2020.

\begin{tabular}{|c|c|c|c|c|c|c|}
\hline \multirow[b]{2}{*}{ Year } & \multicolumn{3}{|c|}{$\begin{array}{l}\text { Tourist arrivals (domestic and } \\
\text { foreign) }\end{array}$} & \multicolumn{3}{|c|}{$\begin{array}{c}\text { Overnight stays of tourists (domestic } \\
\text { and foreign) }\end{array}$} \\
\hline & $\begin{array}{l}\text { Republic } \\
\text { of Serbia }\end{array}$ & $\begin{array}{c}\text { Region of } \\
\text { Southern } \\
\text { and } \\
\text { Eastern } \\
\text { Serbia }\end{array}$ & $\begin{array}{c}\text { Participation } \\
\text { of the region } \\
\text { in the total } \\
\text { number of } \\
\text { arrivals }\end{array}$ & $\begin{array}{l}\text { Republic } \\
\text { of Serbia }\end{array}$ & $\begin{array}{l}\text { Region of } \\
\text { Southern } \\
\text { and } \\
\text { Eastern } \\
\text { Serbia }\end{array}$ & $\begin{array}{l}\text { Participation } \\
\text { of the region } \\
\text { in the total } \\
\text { number of } \\
\text { overnight } \\
\text { stays }\end{array}$ \\
\hline 2010. & $2,000,597$ & 352,553 & & 515 & $1,314,707$ & $20.5 \%$ \\
\hline 2011. & $2,068,610$ & 362,049 & $5 \%$ & $6,644,738$ & $1,350,521$ & $20.3 \%$ \\
\hline 2012. & $2,079,643$ & 353,706 & & $6,484,702$ & $1,315,434$ & $20.3 \%$ \\
\hline 2013. & $2,192,435$ & 334,809 & $3 \%$ & $6,567,460$ & $1,106,177$ & $16.8 \%$ \\
\hline 2014. & $2,192,268$ & 329,529 & $15.0 \%$ & 275 & 995,948 & $16.4 \%$ \\
\hline 2015. & $2,437,165$ & 361,778 & $14.8 \%$ & $6,651,852$ & $1,066,998$ & $16.0 \%$ \\
\hline 2016. & $2,753,591$ & 397,384 & $14.4 \%$ & $7,533,739$ & $1,128,543$ & $15.0 \%$ \\
\hline 2017. & $3,085,866$ & 467,772 & $15.2 \%$ & $8,325,144$ & $1,310,542$ & $15.7 \%$ \\
\hline 2018. & $3,430,522$ & 547,417 & $15.9 \%$ & $9,336,103$ & $1,613,836$ & $17.3 \%$ \\
\hline 2019. & $3,689,983$ & 610,293 & $16.5 \%$ & $10,073,299$ & $1,818,657$ & $18.1 \%$ \\
\hline 2020. & $1,820,021$ & 395,961 & $21.8 \%$ & $6,201,290$ & $1,528,528$ & $24.6 \%$ \\
\hline
\end{tabular}

Source: Statistical Office of the Republic of Serbia, (2021a, 2021b)

Table 1 shows the participation of the region of Southern and Eastern Serbia in the total number of tourist arrivals and overnight stays in the Republic of Serbia in the period 2010-2020, according to the data of the Republic Statistical Office. The data from Table 1 show that from 2010 to 2013 , the region participated with about $17 \%$ in the total number of tourist arrivals. Over the next four years, the region's share in the total number of tourist arrivals will gradually decrease. From 2017, there will be a gradual increase in the participation of the region, and in 2020 the participation of 
the region in the total number of tourist arrivals will be $21.8 \%$. The share of the region in the total number of tourist nights in the first three years of the observed period was about 20\%. In the following years, that participation will decrease, so that from 2018, the region will start to record a larger share in the total number of tourist nights. In 2020, that share is $24.6 \%$. In the year marked by the Covid-19 pandemic, there were $35 \%$ fewer arrivals and $16 \%$ fewer tourist nights in the region of Southern and Eastern Serbia compared to the previous year. However, the share of the region in the total number of tourist arrivals and overnight stays is higher compared to 2019, so that the region in the year of the Covid-19 pandemic was immediately behind the region of Šumadija and Western Serbia, if we participate in the total number of arrivals and overnight stays tourist.

Table 2: Tourist arrivals in the region of Southern and Eastern Serbia in the period 2010-2020.

\begin{tabular}{|c|c|c|c|}
\hline \multirow{2}{*}{ Year } & \multicolumn{3}{|c|}{ Tourist arrivals } \\
\cline { 2 - 4 } & Domestic & Foreign & Total \\
\hline 2010. & 274,400 & 78,153 & 352,553 \\
\hline 2011. & 285,500 & 76,549 & 362,049 \\
\hline 2012. & 275,073 & 78,633 & 353,706 \\
\hline 2013. & 251,673 & 83,136 & 334,809 \\
\hline 2014. & 233,013 & 96,516 & 329,529 \\
\hline 2015. & 252,910 & 108,868 & 361,778 \\
\hline 2016. & 274,758 & 122,626 & 397,384 \\
\hline 2017. & 312,551 & 155,221 & 467,772 \\
\hline 2018. & 362,665 & 184,752 & 547,417 \\
\hline 2019. & 403,954 & 206,339 & 610,293 \\
\hline 2020. & 339,306 & 56,655 & 395,961 \\
\hline
\end{tabular}

Source: Statistical Office of the Republic of Serbia, (2021a, 2021b),

Table 2 shows the number of arrivals of domestic and foreign tourists in the region of Southern and Eastern Serbia in the period 2010-2020, according to the data of the Republic Statistical Office. Based on the data from the table, it can be seen that the number of arrivals of domestic tourists is much higher in relation to the number of arrivals of foreign tourists in the region of Southern and Eastern Serbia. Since 2015, there has been an evident increase in the number of domestic arrivals, while the number of foreign tourist arrivals has been steadily increasing since 2012. The number of arrivals of domestic tourists in the region of Southern and Eastern Serbia in 2020 is lower by $16 \%$, while the number of arrivals of foreign tourists is lower by $72 \%$ compared to 2019 . 
Table 3 shows the number of overnight stays that domestic and foreign tourists realized in the region of Southern and Eastern Serbia in the period 2010-2020, according to the Republic Statistical Office. The data show a significantly higher number of overnight stays realized by domestic tourists compared to foreign tourists. In the period from 2011 to 2015, a decrease in the number of overnight stays of domestic tourists in the region was noticeable. In the following years, the number of overnight stays realized by domestic tourists will increase, with the largest number of overnight stays in the observed period realized in 2019. In the observed ten-year period, there is an evident increase in the number of overnight stays realized by foreign tourists, whereby in 2019 there were three times more overnight stays of foreign tourists compared to 2010. It can be said that the year before the beginning of the Covid-19 pandemic was the best for the region of Southern and Eastern Serbia when the number of arrivals and overnight stays of domestic and foreign tourists is observed. In the year marked by the pandemic, the number of overnight stays of domestic tourists in the region of Southern and Eastern Serbia decreased by only 1.6\%, while the number of overnight stays of foreign tourists decreased by $63.3 \%$ compared to 2019 .

Table 3: Overnight stays in the region of Southern and Eastern Serbia in the period 2010-2020.

\begin{tabular}{|c|c|c|c|}
\hline \multirow{2}{*}{ Year } & \multicolumn{3}{|c|}{ Overnight stays of tourists } \\
\cline { 2 - 4 } & Domestic & Foreign & Total \\
\hline 2010. & $1,185,410$ & 129,297 & $1,314,707$ \\
\hline 2011. & $1,217,103$ & 133,418 & $1,350,521$ \\
\hline 2012. & $1,163,491$ & 151,943 & $1,315,434$ \\
\hline 2013. & 957,431 & 148,746 & $1,106,177$ \\
\hline 2014. & 805,322 & 190,626 & 995,948 \\
\hline 2015. & 855,685 & 211,313 & $1,066,998$ \\
\hline 2016. & 902,795 & 225,748 & $1,128,543$ \\
\hline 2017. & $1,027,696$ & 282,846 & $1,310,542$ \\
\hline 2018. & $1,267,918$ & 345,918 & $1,613,836$ \\
\hline 2019. & $1,394,778$ & 423,879 & $1,818,657$ \\
\hline 2020. & $1,373,078$ & 155,450 & $1,528,528$ \\
\hline
\end{tabular}

Source: Statistical Office of the Republic of Serbia, (2021a, 2021b)

The pandemic affected the decrease in the number of tourist arrivals and overnight stays in the region of Southern and Eastern Serbia compared to the previous year, but the region's share in the total number of tourist arrivals and overnight stays in the country is higher compared to 2019. This 
region was the second region in the country in the year of the Covid-19 pandemic when the participation of the region in the total number of tourist arrivals and overnight stays is observed. Destinations in the region that record a slightly higher total number of tourists in 2020 compared to 2019 are Sokobanja and Stara Planina. According to the data of the Republic Statistical Office, Sokobanja is the second most visited destination in the country in the year of the pandemic, when it comes to spas. When it comes to cities that are categorized as tourist places, Nis is in third place. The year 2020 will be remembered as one of the most difficult years for tourism in the whole world, in recent history.

\section{Conclusion}

Given that a number of restrictions remain in place and that it is not possible to predict how long the epidemic will last, it is difficult to estimate when the recovery of tourism will begin. Therefore, national and local tourist organizations will have to make a great effort in the realization of promotional activities aimed at foreign markets, but also towards domestic tourists in order to travel more within their country. In the conditions of pandemic and crisis, tourism is the activity that suffers the greatest losses, but it is also the activity that will recover faster after the crisis in relation to other activities.

In order to valorize comparative advantages, improve the quality of the existing offer and improve the competitive position of the Southern and Eastern Serbia region on the domestic and international tourist market, it is necessary to single out unique advantages of tourist destinations and create a positive image of tourist destinations in Southern and Eastern Serbia.

The existence of an appropriate resource base is one of the main preconditions for the development of tourism in a particular area. Areas that have a unique resource base have a comparative advantage in tourism development. It is not enough, however, to have tourist resources and to have an appropriate comparative advantage on that basis. It is necessary to use tourist resources in the right way and turn them into tourist attractions, which will be an integral part of the tourist offer of an area. That is, it is necessary to turn the comparative advantage that the area has in the development of tourism into a competitive advantage.

The region of Southern and Eastern Serbia has a very significant resource base and has a comparative advantage for the development of tourism. The 
resource base in this area, however, has not been adequately utilized. The region has a certain level of competitiveness in the tourism market, but this level should be increased by converting comparative advantages for tourism development into competitive advantages.

An important national priority, as well as the priority of the region of Southern and Eastern Serbia in terms of sustainable development, is the protection of the environment and the rational use of natural resources. Maintaining and improving the quality of the environment is very important for the tourism sector because a clean and healthy environment is one of the main preconditions for the successful development of tourism in the region. On the other hand, unsustainable tourism development can have negative effects on the environment (pressure on natural resources, waste generation, air, water pollution, etc.).

Despite the great potential that the region of Southern and Eastern Serbia has, the development of tourism in the current period is not at a satisfactory level. Numerous problems and factors that limit the development of selective types of tourism in this area have contributed to this.

It can be concluded that one of the main problems and limiting factors in the development of tourism in the area of Southern and Eastern Serbia is the inadequate traffic infrastructure. For further development of tourism in the region and increase in the number of domestic and foreign tourists, it is necessary to reconstruct, modernize and improve the quality of traffic infrastructure. In some districts of the region of Southern and Eastern Serbia, there are very attractive tourist values, which are difficult for tourists to access due to poor, above all, local roads. Maintenance of infrastructural capacities is necessary in order to increase technical reliability, safety, improve the quality of transport and increase the availability of space that has attractive natural and anthropogenic resources.

The main goal after the pandemic should be the development of tourism that will contribute to the social and economic progress of individual districts, but also the entire region. Rational use of value and successful management of tourist destinations should attract future investors, which can further enhance the development and improve the image of the region of Southern and Eastern Serbia as tourist destinations. Therefore, it is necessary to create a model of rational use of values and adequate management of tourism development in the region. 
Improving the tourist offer should aim at better positioning of destinations on the market, increase of tourist traffic and income from tourism. In order to improve the tourist offer in the tourist destinations of the region of Southern and Eastern Serbia, it is necessary to take measures and activities aimed at: continuous research of tourist demand; development of new tourist products in accordance with the requirements of tourist demand; development of specific segments of the tourist offer in the destinations of the region of Southern and Eastern Serbia; development of new and modernization of existing tourist information centers; more intensive promotion of the tourist offer; connecting and cooperating all actors in the field of tourism; planning and implementation of projects that will contribute to better content and quality of the tourist offer in the destinations of the region of Southern and Eastern Serbia. The support and assistance of the state is of great importance for the survival of the subjects of the tourist economy in the conditions of a pandemic. In addition to measures aimed at the survival of these entities in the conditions caused by the pandemic, it is very important to plan a set of incentive measures that should, in the period after the pandemic, contribute to the fastest recovery of tourism.

\section{References}

1. Ćorluka, G., Matošević Radić, M. Geić, S. (2013). Selective Forms of Tourism - the Way of Extending the Summer Season. Economy Transdisciplinarity Cognition, Vol. 16, No. 2, 88-96.

2. Ilić, D., Stamenković, P. (2019). Tourism development limitations and tourist traffic analysis in South and Eastern Serbia. TISC - Tourism International Scientific Conference, Vrnjačka Banja, 4(2), 398-414.

3. Krešić, D., Mikulić, J. (2020). Scenarij faznog pristupa oporavku turističkog tržišta nakon Covid -19 pandemije, http://www.iztzg.hr/files/ file/RADOVI/2020/COVID-19/Kre\%C5\%A1i\%C4\%87-D_Mikuli\%C4 \%87-J_2020.pdf, (26 January 2021).

4. Mojić, J. (2012). Pozicioniranje prostora Južne Srbije u cilju turističkog razvoja. Zbornik radova Departmana za geografiju, turizam i hotelijerstvo, Vol. 41, 139-151. 
5. Praščević, A. (2020). Ekonomski šok pandemije Covid 19 - prekretnica u globalnim ekonomskim kretanjima. Ekonomske ideje i praksa, Vol. 37, No. 1, 7-22.

6. Sharma, G., Thomas, A., Paul, J. (2020). Reviving tourism industry postCovid-19: A resilience - based framework. Tourism Management Perspectives, Vol. 37, 100786.

7. Stamenković, P., Đeri, L. (2016). Food as a tourism competitiveness factor of Jablanica District in Serbia. Economics of Agriculture, Vol. 63, No. 4, 1253-1263.

8. Stamenković, P., Đeri, L. (2018). Environment as a tourism competitiveness factor of Jablanica District in Serbia. $7^{\text {th }}$ International Congress Hotelplan 2018, Belgrade, 613-622.

9. Stamenković, P., Ilić, D. (2017). Tourism image factors of Jablanica District in Serbia: Perception of internal stakeholders. TISC - Tourism International Scientific Conference, Vrnjačka Banja, 2(1), 641-658.

10. Stanković, S. (2003). Životna sredina, turizam i prostorno planiranje. Glasnik srpskog geografskog društva, Vol. 83, No. 2, 19-30.

11. Statistical Office of the Republic of Serbia, (2021a), Opštine i regioni $u$ Republici Srbiji [Municipalities and regions in the Republic of Serbia] 2011., 2012., 2013., 2014., 2015., 2016, 2017, 2018., 2019., 2020., https://www.stat.gov.rs/sr-cyrl/publikacije/?d=13\&r=, (15 January 2021).

12. Statistical Office of the Republic of Serbia, (2021b), Statistika ugostiteljstva i turizma - Turistički promet, decembar 2020., [Catering and tourism statistics - Tourist turnover, December 2020], No. 24, Year LXXI, https://publikacije.stat.gov.rs/G2021/Pdf/G20211024.pdf, (16 January 2021).

13. Telišman-Košuta, N. (2020), Turizam nakon doba korone: Što će biti drugačije? Što može biti bolje?, http://www.iztzg.hr/files/file/RADOVI/ 2020/COVID-19/Teli\%C5\%A1man-Ko\%C5\%A1uta-N_2020.pdf, February 2021).

14. World Tourism Organization - UNWTO, (2021), https://www.unwto.org/ (20 February 2021). 